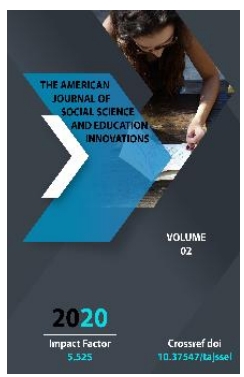

\title{
Interactive Learning Technology
}

\author{
Dilafruz Furkatovna Jabborova \\ Teacher Of "Preschool Education" Navoi State Pedagogical Institute, Navoi, Uzbekistan \\ Shirinboy Sharofovich Olimov \\ Doctor Of Pedagogical Sciences, Professor, Bukhara State University, Bukhara, Uzbekistan
}

Copyright: Original content from this work may be used under the terms of the creative commons attributes 4.0 licence.

\section{ABSTRACT}

In this article the authors explain the interactive technology of teaching, its essence, its forms and features. Features of interactive learning technologies include motivation, purposefulness, new information delivery, interactive exercises, new products, reflexion, evaluation and homework. Soft and active methods, approaches to interactive methods are highlighted.

\section{KEYWORDS}

Interactive learning, technology, method, motivation, reflexion, interactive exercises, slow and active teaching methods.

\section{INTRODUCTION}

In pedagogical practice, the term "active methods and forms of learning" has long been used. It brings together a group of pedagogical technologies that achieve a high level of student learning activity. Recently, another term has become widespread - "interactive learning." Modern science of education has come close to the moment when there was a need to create pedagogical technologies that provide the most important thing in the educational process - the development of the personality of each student, his activity. It is necessary to create such learning conditions so that the student strives to obtain new results of his work and to successfully apply them in practice in the future. 


\section{MATERIAL AND METHODS}

The concept of "interaction" (from the English. Interaction - interaction) arose for the first time in sociology and social psychology. The theory of symbolic interactionism (the founder is the American philosopher J. Mead) is characterized by a consideration of the development and life of a person, a person's creation of his "l" in situations of communication and interaction with other people [1]. Interactive learning is a special form of organization of the educational process, the essence of which is the joint activity of students on the development of educational material to solve common but significant problems for everyone, in the exchange of knowledge, ideas, ways of working.

Traditional learning sets itself the goal of transmitting to students and learning as much knowledge as possible. The teacher broadcasts information that is already meaningful and differentiated by him, defines the skills that he needs, from his point of view, to develop in students. The task of students is to reproduce the knowledge created by others as fully and accurately as possible. The knowledge obtained in the process of such training is encyclopedic in nature, it represents a certain amount of information on various academic subjects, which in the student's mind exists in the form of thematic blocks that do not always have semantic connections.

\section{RESULTS AND DISCUSSION}

In the context of interactive learning, knowledge takes other forms. On the one hand, they represent certain information about the world. A feature of this information is that the student receives it not in the form of a ready-made system from the teacher, but in the process of their own activity. The teacher must create situations in which the student is active, in which he asks, acts. In such situations, "he, together with others, acquires abilities that allow him to transform into knowledge what was originally a problem or an obstacle." On the other hand, the student in the process of interaction in the classroom with other students, the teacher masters the system of tried (tested) ways of working in relation to himself, society, the world in general, assimilates various mechanisms for searching for knowledge. Therefore, the knowledge acquired by students is at the same time a tool for their independent acquisition. Thus, the goal of active learning is the creation by the teacher of the conditions in which the student himself will discover, acquire and construct knowledge. This is a fundamental difference between the goals of active learning and the goals of the traditional education system.

Interactive learning is such an organization of the educational process in which almost all students are involved in the learning process. The structure of the lesson, conducted in an interactive mode, includes 8 stages. I will dwell on the features of the organization of each of them.

Motivation. In order to create motivation, along with problematic questions and tasks, one needs to use scenes, reading dictionary articles, newspaper excerpts, listening to statistical data (for example, about the impact of developing reading skills of younger students on their further education), different definitions of one concept. When organizing this stage, it is always necessary to take into account the fact that one student is prompted to take active actions, causes a violent reaction, the other remains indifferent or leads to an insignificant effect, so you need to try to change the way of motivation from lesson to lesson, improve them.

Communication goals (goal setting). The objectives of interactive learning lessons are different from traditional ones. In the first place are goals related to student knowledge. Then the goals associated with the formed skills are set. In third place are goals that call values. This stage is of great importance: firstly, 
it allows all further activities of students to be focused, i.e. each student learns what the final result will be, what he should strive for; secondly, at this stage, the teacher teaches students to formulate the objectives of the lesson - one of the teacher's professional skills.

Providing new information. Since all the concepts, to one degree or another, are already familiar to students, it is recommended to begin this stage with a brainstorming session. The thoughts presented by students are written on a blackboard in a column and numbered. This type of work helps to select what students already know, and what is really incomprehensible, unfamiliar. New information is provided mainly on Worksheets, where questions and tasks are recorded at the top, and information is placed below. To provide information, textbooks, dictionaries, monographic articles, and the teacher's word are also used.

Interactive exercises. Small group work is one of the most popular strategies, as it gives all students (including shy ones) the opportunity to participate in work, to practice skills of cooperation, interpersonal communication (in particular, the ability to actively listen, develop a common opinion, and resolve disagreements). All this is often impossible in a large team. Work in a small group is an integral part of many interactive methods, for example, such as mosaics, debates, public hearings, almost all kinds of imitations, etc. When organizing group work, one should pay attention to the following aspects. You need to make sure that students have the knowledge and skills necessary to complete a group assignment. Lack of knowledge will soon make itself felt - students will not make efforts to complete the task. We must try to make our instructions as clear as possible. It is unlikely that a group will be able to take more than one or two, even very clear, instructions at a time, so you need to write down instructions on the board and / or cards. It is necessary to provide the group with enough time to complete the task.

New Product. The logical conclusion of work on new knowledge is the creation of a new product. Given the large amount of information learned in the lesson, and the limited time, students are invited to draw independent conclusions to express their point of view, to perform a new, previously unattained task, as a new product.

Reflection. This stage involves summarizing the activities of students. Reflections contribute to the questions: - What did you especially like? What have you learned? How will this knowledge come in the future? What conclusions can be drawn from today's lesson? These questions allow students to highlight the most important, new, what they learned in the lesson, to realize where, how, and for what purposes this knowledge can be applied.

Evaluation This question is the most difficult for teachers working online. Evaluation should stimulate students in subsequent classes. For the first time, if everyone worked actively, with desire, they are given the highest score to all members of the group. Further assessment is entrusted to the team leader. This method of organizing assessment has a professional orientation - it teaches students to evaluate the work of others. You can use this approach: each group member evaluates each, i.e. marks each comrade in the rating sheet. The teacher collects the papers and displays the average score. Finally, you can take advantage of student self-esteem.

Homework. After conducting lessons in an interactive mode, tasks are offered that require a creative rethinking of the material studied: write an essay - a miniature on the topic, express your point of view on the problem, and conduct a stylistic experiment. It is believed that such a task is more consistent with the nature of interactive learning. 
The passive method is a form of interaction between students and teachers, in which the teacher is the main actor and the manager of the lesson, and students act as passive listeners subordinate to the teacher's guidelines. From the point of view of modern pedagogical technologies and the effectiveness of students learning the teaching material, the passive method is considered the most inefficient, but, despite this, it has some advantages. This is a relatively easy preparation for the lesson by the teacher and the opportunity to present a relatively larger amount of educational material in the limited time frame of the lesson. Given these advantages, many teachers prefer the passive method to other methods.

The active method is a form of interaction between students and teachers, in which the teacher and students interact with each other during the lesson and the students here are not passive listeners, but active participants in the lesson. If the teacher was the main character in the passive lesson, then here the teacher and students are on an equal footing. If passive methods presupposed an autocratic style of interaction, then active ones more presuppose a democratic style. Many between active and interactive methods put an equal sign, however, despite their commonality, they have differences.

Interactive methods can be considered as the most modern form of active methods.

Interactive method. Interactive ("Inter" is mutual, "act" means acting) - means to interact, is in the mode of conversation, dialogue with someone. In other words, unlike active methods, interactive ones are oriented towards a wider interaction of students not only with the teacher, but also with each other and at the dominance of student activity in the learning process. The teacher's place in interactive lessons is reduced to the direction of students' activities towards achieving the objectives of the lesson. The teacher also develops a lesson plan (usually these are interactive exercises and assignments, during which the student learns the material).

\section{CONCLUSIONS}

Therefore, the main components of interactive lessons are interactive exercises and assignments that are performed by students. An important difference between interactive exercises and assignments from the usual ones is that when they perform, their students not only consolidate the material they have already learned, but also learn new material. Interactive learning is, first of all, interactive learning, during which interaction is carried out. This training provides positive motivation of students to study the material, the formation of sustainable cognitive interest of students in the subject, improving the quality of knowledge, creating pedagogical conditions for the development of students' abilities. Classes built in an interactive mode cause noticeable interest among students, primarily because the usual and somewhat monotonous order of work in the lesson is violated, the interactive teaching method allows everyone to be not in the role of a passive listener, but in the role of an active participant, organizer of the educational process. In the traditional system, the teacher usually relies on a strong student, because he quickly "grabs" the material, remembers it faster, and the weak "stays" in the lesson. The lessons conducted in an interactive mode allow you to include all students in active work, to ensure that each student is able to participate in solving problems, as a result, the weak gain some confidence in their own abilities, and the strong ones benefit, helping their comrades understand the material. If the teacher and the textbook were the main and most competent sources of knowledge in the traditional teaching system, then in the new paradigm, the teacher acts as the organizer of the students' independent cognitive activity, as a competent consultant and assistant, while students receive knowledge as a result of their active cognitive activity [6]. In the process of 
work, students develop communication skills, the ability to cooperate and interact, develop critical thinking, which is necessary for their future professional activities.

\section{REFERENCES}

1. Frolov S.S. Sociology. History of Theoretical Sociology. - M .: Nauka, 2008.221s.

2. Babansky Yu.K. Teaching methods in a modern comprehensive school. - M., 2005.

3. Zankov L.V.Visualization and activation of students in learning. -M.: Knowledge, 1960. $162 \mathrm{p}$.

4. New pedagogical and information technologies in the education system. / E.S. Polat, M.Yu. Bukharkina, M.V. Moiseeva, A.E. Petrov. - M.: Publishing Center "Academy", 2004.

5. Zankov L.V. Selected pedagogical works. M .: Pedagogy, 1990.

6. Nagornova A.Yu. The willingness of future teachers to apply special skills for correction of mental conditions of students // Bulletin of the Volgograd State Pedagogical University. 2010.V. 45. No. 1. S. $174-178$

7. Shamsitdinova, M. G. (2020). INTERCULTURAL COMMUNICATION AND PROBLEMS OF TEACHING ENGLISH TO THE STUDENTSNONLINGUISTS. Theoretical \& Applied Science, (4), 1024-1026.

8. Shamsitdinova M. THE IMPACT OF INFORMATION TECHNOLOGIES ON DISTANCE EDUCATION DURING PANDEMIC IN THE REPUBLIC OF UZBEKISTAN. PalArch's Journal of Archaeology of Egypt / Egyptology. ISSN: 1567-214X, Netherlands, pp. 89628967

9. Boltabayevich, B. B., \& Shodievna, B. O. (2020). Individual Approach To The Formation of Artistic And Creative
Talents Of Students In Art Schools. The American Journal of Social Science and Education Innovations, 2(08), 637-642.

10. Boltaboevich, B. B. (2020). Formation of the skills of portraying the future teacher of fine arts in pencil drawing. ACADEMICIA: An International Multidisciplinary Research Journal, 10(5), 1122-1127.

11. Baymetov, B. B., \& Sharipjonov, M. S. O. (2020). Development Of Students' Descriptive Competencies In Pencil Drawing Practice. The American Journal of Social Science and Education Innovations, 2(08), 261-267.

12. Salakhova Z., M.Shamsitdinova. ADVANCED PEDOGOGICAL TECHNOLOGIES IN EDUCATION IN THE 21-ST CENTURY. International Scientific Journal Theoretical \& Applied Science, USA, pp. 743-746. 